\title{
Evidence of Phytotoxicity and Genotoxicity in Hordeum vulgare L. Exposed to $\mathrm{CeO}_{2}$ and $\mathrm{TiO}_{2}$ Nanoparticles
}

\author{
Alessandro Mattiello', Antonio Filippi' ${ }^{1}$, Filip Pošćić1, Rita Musetti' ${ }^{1}$ Maria C. Salvatici' ${ }^{2}$, \\ Cristiana Giordano ${ }^{2,3}$, Massimo Vischi' ${ }^{1}$, Alberto Bertolini' ${ }^{1}$ and Luca Marchiol' * \\ ${ }^{1}$ Department of Agriculture and Environmental Sciences, University of Udine, Udine, Italy, ${ }^{2}$ Centro di Microscopie \\ Elettroniche "Laura Bonzi", Istituto di Chimica dei Composti OrganoMetallici, Consiglio Nazionale delle Ricerche, Firenze, \\ Italy, ${ }^{3}$ Tree and Timber Institute, Istituto Per La Valorizzazione del Legno e delle Specie Arboree-CNR, Firenze, Italy
}

\section{OPEN ACCESS}

Edited by: Nelson Marmiroli, University of Parma, Italy

Reviewed by: Margarita Sánchez-Domínguez, Centro de Investigación en Materiales Avanzados, S.C., Mexico Jozsef Dudas,

Medical University of Innsbruck, Austria

*Correspondence: Luca Marchiol marchio/@uniud.it

Specialty section:

This article was submitted to Functional Plant Ecology, a section of the journal Frontiers in Plant Science

Received: 12 September 2015 Accepted: 09 November 2015 Published: 25 November 2015

Citation:

Mattiello A, Filippi A, Pošćić $F$ Musetti R, Salvatici MC, Giordano C, Vischi M, Bertolini A and Marchiol L

(2015) Evidence of Phytotoxicity and Genotoxicity in Hordeum vulgare L. Exposed to $\mathrm{CeO}_{2}$ and $\mathrm{TiO}_{2}$ Nanoparticles.

Front. Plant Sci. 6:1043. doi: 10.3389/fpls.2015.01043
Engineered nanoscale materials (ENMs) are considered emerging contaminants since they are perceived as a potential threat to the environment and the human health. The reactions of living organisms when exposed to metal nanoparticles (NPs) or NPs of different size are not well known. Very few studies on NPs-plant interactions have been published, so far. For this reason there is also great concern regarding the potential NPs impact to food safety. Early genotoxic and phytotoxic effects of cerium oxide NPs $\left(n \mathrm{CeO}_{2}\right)$ and titanium dioxide NPs $\left(n \mathrm{TiO}_{2}\right)$ were investigated in seedlings of Hordeum vulgare L. Caryopses were exposed to an aqueous dispersion of $n \mathrm{CeO}_{2}$ and $n \mathrm{TiO}_{2}$ at, respectively 0, 500, 1000, and $2000 \mathrm{mg} \mathrm{I}^{-1}$ for 7 days. Genotoxicity was studied by Randomly Amplified Polymorphism DNA (RAPDs) and mitotic index on root tip cells. Differences between treated and control plants were observed in RAPD banding patterns as well as at the chromosomal level with a reduction of cell divisions. At cellular level we monitored the oxidative stress of treated plants in terms of reactive oxygen species (ROS) generation and ATP content. Again $n \mathrm{CeO}_{2}$ influenced clearly these two physiological parameters, while $n \mathrm{TiO}_{2}$ were ineffective. In particular, the dose $500 \mathrm{mg}$ $\mathrm{I}^{-1}$ showed the highest increase regarding both ROS generation and ATP content; the phenomenon were detectable, at different extent, both at root and shoot level. Total $\mathrm{Ce}$ and Ti concentration in seedlings was detected by ICP-OES. TEM EDSX microanalysis demonstrated the presence of aggregates of $n \mathrm{CeO}_{2}$ and $n \mathrm{TiO}_{2}$ within root cells of barley. $n \mathrm{CeO}_{2}$ induced modifications in the chromatin aggregation mode in the nuclei of both root and shoot cells.

Keywords: barley, cerium oxide nanoparticles, titanium oxide nanoparticles, genotoxicity, oxidative stress

\section{INTRODUCTION}

It is estimated that by 2020 about six million people will be employed worldwide in industries that use nanotechnologies, which will have the potential to produce goods for a market of more than 3,000 billion dollars (Roco, 2011). There is therefore a tumultuous development of new materials justified by a rapid growth of technological and commercial applications. Model simulations demonstrated that flows of engineered nanomaterials (ENMs) are able to reach several natural 
ecosystems (Colman et al., 2013). Cerium oxide nanoparticles $\left(\mathrm{NPs} ; n \mathrm{CeO}_{2}\right)$ and titanium oxide NPs $\left(n \mathrm{TiO}_{2}\right)$ are among the top ten most produced ENMs by mass (Keller et al., 2013) and used in cosmetics industries, in solar cells, paints, cements, coatings, in agriculture and the food industry (Gogos et al., 2012; Piccinno et al., 2012; Parisi et al., 2015). $n \mathrm{CeO}_{2}$ and $n \mathrm{TiO}_{2}$ were included in the list of ENMs of priority for immediate testing by the Organization for Economic Cooperation and Development (OECD, 2010). From point sources (e.g., discharges of wastewaters from industries or landfills), such materials will tend to accumulate in sediments and soils, exposing the organisms inhabiting these environments to potential risks (Liu and Cohen, 2014).

Plants are able to assimilate metal nanoparticles (MeNPs) largely depending on the type of plant and the size of MeNPs (Rico et al., 2011). In addition, the primary particle size of MeNPs is relevant for their bioavailability and therefore their toxicity (Van Hoecke et al., 2009), also raising questions on the potential for MeNPs exposure of crops and food safety (Hong et al., 2013). Experimental evidences were reported by Zhang et al. (2011) which studied the $n \mathrm{CeO}_{2}$ uptake and translocation in cucumber, reporting an higher Ce assimilation in plants treated with $7 \mathrm{~nm}$ Ce than $25 \mathrm{~nm}$ ones. Clément et al. (2013) reported similar results for $n \mathrm{TiO}_{2}$ on rapeseed plantlets treated with 14-25 nm particles. Another functional property that influences the MeNPs plant assimilation is the agglomeration/aggregation status that in turn is influenced directly by the zeta-potential (Navarro et al., 2008). Song et al. (2013a) demonstrated a negative correlation between $n \mathrm{TiO}_{2}$ agglomeration/aggregation and assimilation in tomato. A similar behavior could be hypothesized also for $n \mathrm{CeO}_{2}$.

Although there are potential positive applications of ENMs in agriculture (Parisi et al., 2015), studies on the toxicity of MeNPs have shown early negative consequences on crops due to genotoxic and phytotoxic effects (Miralles et al., 2012; GardeaTorresdey et al., 2014). From an ecological point of view, this raises questions about potential risks due to the input of MeNPs in the food chain. Early plant MeNPs toxicity can be measured observing seed germination, root elongation, DNA mutations (López-Moreno et al., 2010a; Atha et al., 2012) or changes in biochemical parameters (Rico et al., 2013; Schwabe et al., 2013).

The aims of this study were to determine the early phytotoxic and genotoxic effects of $n \mathrm{CeO}_{2}$ and $n \mathrm{TiO}_{2}$ on barley (Hordeum vulgare L.) plants. The FAO ranks barley fourth in the top five cereals in the world ordered based on production tonnage (FAOSTAT, 2014) and the cereal is one of the major crops grown worldwide for human and animal consumption. Suspensions of $n \mathrm{CeO}_{2}$ and $n \mathrm{TiO}_{2}$ were prepared at $0,500,1000$, and $2000 \mathrm{mg}$ $1^{-1}$. Phytotoxicity of NPs was determined through percentage of germination and root elongation, ATP and ROS generation in root and leaf cells. Genotoxicity was investigated by the mitotic index and RAPDs. Ce and Ti uptake and translocation within seedling tissues were determined by inductively coupled plasma-optical emission spectroscopy (ICP-OES), while $n \mathrm{CeO}_{2}$ and $n \mathrm{TiO}_{2}$ within plant cells were detected by transmission electronic microscope and energy dispersive $\mathrm{x}$-ray spectrometer (TEM-EDX).

\section{MATERIALS AND METHODS}

\section{Nanoparticles Characterization}

The cerium ${ }^{(\mathrm{IV})}$ oxide $\left(n \mathrm{CeO}_{2}\right)$ and titanium ${ }^{(\mathrm{IV})}$ oxide anatase $\left(n \mathrm{TiO}_{2}\right)$ powders with a nominal average particle size $<25 \mathrm{~nm}$ were purchased from Sigma-Aldrich (Milwaukee, WI, USA). The specific surface area of the $n \mathrm{CeO}_{2}$ and $n \mathrm{TiO}_{2}$ was measured by the Brunauer-Emmett-Teller (BET) method by using the Surface Area and Pore Size Analyzer SA 3100 plus (Beckman Coulter, USA).

The $n \mathrm{CeO}_{2}$ and $n \mathrm{TiO}_{2}$ powders were suspended in deionized water at a concentration of $1000 \mathrm{mg} \mathrm{l}^{-1}$ and sonicated at $60^{\circ} \mathrm{C}$ for $30 \mathrm{~min}$. The suspensions were characterized for $\mathrm{Z}$-average size, measured as hydrodynamic diameter, zeta potential, via electrophoretic mobility, and polydispersity index (PDI), calculated from the signal intensity, by the dynamic light scattering (DLS) method using the Nano ZS90 (Malvern Instruments, $\mathrm{UK})$. The $n \mathrm{CeO}_{2}$ and $n \mathrm{TiO}_{2}$ powder suspensions at three different concentrations (500, 1000, and $2000 \mathrm{mg} \mathrm{l}^{-1}$ ) were prepared in $\mathrm{MilliQ}^{\circledR}$ water by sonication for $30 \mathrm{~min}$ at room temperature and then stirred for $15 \mathrm{~min}$. The range of concentrations $\left(0,500,1000\right.$, and $\left.2000 \mathrm{mg} \mathrm{L}^{-1}\right)$ was chosen according to Yang and Watts (2005), Lin and Xing (2007), and López-Moreno et al. (2010a).

\section{Seed Germination and Root Elongation}

Caryopses of $H$. vulgare L. var. Tunika were provided by S.I.S. Società Italiana Sementi (San Lazzaro di Savena, Bologna, Italy). The caryopses were sterilized by orbital agitation with $70 \%$ ethanol for $2 \mathrm{~min}$ and then with 5\% sodium hypochlorite plus some drops of Tween 80 for $30 \mathrm{~min}$. They were rinsed six times with sterilized MilliQ ${ }^{\circledR}$ water. All caryopses were transferred in sterile conditions into $15 \mathrm{~mm}$ Petri dishes containing filter paper (Ø $90 \mathrm{~mm}$ Whatman No. 1) soaked with $8 \mathrm{ml}$ of MilliQ ${ }^{\circledR}$ water (control treatment) or $8 \mathrm{ml}$ of $n \mathrm{CeO}_{2}$ or $n \mathrm{TiO}_{2}$ suspensions at different concentrations. The Petri dishes were taped and placed in the dark at $21^{\circ} \mathrm{C}$ for 3 days. The germination percentage was calculated as the ratio of germinated seeds out the total seeds of each Petri dish. A second set of caryopses were treated for 7 days in the same conditions to evaluate root elongation and $\mathrm{Ce}$ and $\mathrm{Ti}$ uptake. The seedlings were photographed and Image J software (Schneider et al., 2012) was used to measure roots length. Root elongation was calculated as the average or the sum of all roots emerged from each seed. The experiments were performed in triplicate.

\section{Mitotic Index}

The germinated seedlings with actively growing roots $(2.5 \mathrm{~cm}$ in length) were placed in the $n \mathrm{CeO}_{2}$ and $n \mathrm{TiO}_{2}$ suspensions $(0,500$, $1000,2000 \mathrm{mg} \mathrm{l}^{-1}$ ) for $24 \mathrm{~h}$. After treatment the root tips were fixed in 3:1 alcohol : acetic acid and then, kept in 70\% ethanol at $4^{\circ} \mathrm{C}$. The root tips were rinsed in deionized water for $5 \mathrm{~min}$, hydrolyzed in $1 \mathrm{~N} \mathrm{HCl}$ for $8 \mathrm{~min}$ at $60^{\circ} \mathrm{C}$, rinsed in deionized water for $5 \mathrm{~min}$, stained in leuco-basic-fuchsine for $45 \mathrm{~min}$ and washed in tap water for $5 \mathrm{~min}$. The root tips were then transferred to $45 \%$ acetic acid for 1 to $5 \mathrm{~min}$, root caps were removed, and 
the roots were dissected to release the meristematic cells. Ten tips per treatment were evaluated and each treatment was replicated three times, for a total of about 10,000 cell observations. The mitotic index was evaluated in Feulgen stained preparations as the percentage of dividing cells out of the total number of cells scored.

\section{Random Amplified Polymorphic DNA (RAPD) Analysis}

The genotoxicity of $n \mathrm{CeO}_{2}$ and $n \mathrm{TiO}_{2}$ was investigated by observing the band profile after a random amplified polymorphic DNA (RAPD) assay on six replicates per treatment obtained from seedlings exposed as for mitotic index experiment. Plant genomic DNA was extracted from root tips using the DNeasy Plant Mini Kit $\left(\right.$ QIAGEN ${ }^{\circledR}$ ) according to manufacturer's protocol. PCR reactions were performed with $30 \mathrm{ng}$ of genomic DNA as a template using six primer pairs: OPA04 (AATCGGGCTG), OPA10 (GTGATCGCAG), OPB01 (GTTTCGCTCC), OPB03 (CATCCCCCTG), OPB12 (CCTTGACGCA), and OPB20 (GGACCCTTAC). The PCR conditions consisted of an initial Taq polymerase activation at $95^{\circ} \mathrm{C}$ for $5 \mathrm{~min}$, followed by 45 cycles of denaturation $\left(95^{\circ} \mathrm{C}, 1 \mathrm{~min}\right)$, annealing $\left(35^{\circ} \mathrm{C}, 1 \mathrm{~min}\right)$, and extension $\left(72^{\circ} \mathrm{C}, 1 \mathrm{~min}\right)$ with a final extension for $10 \mathrm{~min}$ at $72^{\circ} \mathrm{C}$. The PCR products were subjected to electrophoresis on $1.6 \%$ agarose in TBE $0.5 \%$, for $2 \mathrm{~h}$ at $60 \mathrm{~V} / \mathrm{cm}$ stained with GelRed $^{\circledR}$ and photographed for band scoring.

\section{Evaluation of ATP Content}

ATP content was determined by means of the luciferin-luciferase luminometric assay (Lundin, 1984). Root and shoot of each seedling were separated, frozen with liquid nitrogen and ground to a fine powder. Tissue powder $(100 \pm 20 \mathrm{mg}$ FW) was suspended in $1 \mathrm{ml}$ of $50 \mathrm{mM}$ Tris- $\mathrm{HCl}(\mathrm{pH} \mathrm{7.5)}, 0.05 \%(\mathrm{w} / \mathrm{v})$ Triton $\mathrm{X}-100$ and immediately kept at $95^{\circ} \mathrm{C}$ for $3 \mathrm{~min}$ to inactivate any possible hydrolytic activity. After cooling, samples were centrifuged to obtain the cellular soluble fraction in the supernatant. The sample assays were performed in a 96-well plate with ATPlite Luminescence ATP Detection Assay System, (PerkinElmer) according to manufacturer's protocol. Aliquots $(20 \mu \mathrm{l})$ of soluble fraction were mixed with $20 \mu \mathrm{l}$ of ATPlite buffer in $130 \mu \mathrm{l}$ of $50 \mathrm{mM}$ Tris- $\mathrm{HCl}(\mathrm{pH} 7.5)$ and $5 \mathrm{mM} \mathrm{MgCl}_{2}$. Signals were detected by a Multilabel Counter (WALLAC, model 1420, PerkinElmer, Waltham, MA, USA). Actual ATP concentration of each experiment (expressed as nmol ATP g $\mathrm{g}^{-1} \mathrm{f}$. w.) was calculated by a calibration curve obtained with commercially purchased ATP (Sigma, USA) in a 8-100 nM range.

\section{Reactive Oxygen Species (ROS) Determination}

The generation of ROS was monitored by the method of Wang and Joseph (1999), using $2^{\prime}, 7^{\prime}$-dichlorodihydrofluorescein diacetate $\left(\mathrm{H}_{2} \mathrm{DCFDA}\right)$ as a probe. Tissue powder $(0.5 \mathrm{~g} \mathrm{f}$. w.) obtained from both roots and shoots was extracted in $2.5 \mathrm{ml}$ cold acetone and incubated for $4 \mathrm{~h}$ at $4^{\circ} \mathrm{C}$. After centrifugation at $1000 \mathrm{~g}$ for $10 \mathrm{~min}$, the pellet was homogenized in $1 \mathrm{ml}$ of $50 \mathrm{mM}$ Tris- $\mathrm{HCl}$ ( $\mathrm{pH}$ 7.5), $0.4 \mathrm{M}$ sucrose and $1 \mathrm{mM}$ EDTA by
Turrax device. The sample was again centrifuged for $15 \mathrm{~min}$ and the supernatant stored at $-80^{\circ} \mathrm{C}$ until analysis. Aliquots of sample $(20 \mu \mathrm{l})$ were incubated in 96-well microplate with $5 \mu \mathrm{M}$ $\mathrm{H}_{2}$ DCFDA and $180 \mu \mathrm{l}$ of $50 \mathrm{mM}$ Tris-HCl ( $\mathrm{pH}$ 7.5). Detection was performed by fluorimetric assay using Multilabel Counter (WALLAC, model 1420, PerkinElmer) with orbital shaking and reading for $1.75 \mathrm{~h}$ at $5 \mathrm{~min}$ intervals with excitation filter set at $485 \pm 10 \mathrm{~nm}$ and the emission filter set at $530 \pm 10 \mathrm{~nm}$. Values of relative fluorescence (RFU) were expressed as RFU mg $\mathrm{mg}^{-1}$ protein. Protein concentration was estimated by the Bradford (1976) method.

\section{Cerium and Titanium in Seedling Tissues}

The seedlings were washed by agitation with $0.01 \mathrm{M} \mathrm{HNO}_{3}$ for $30 \mathrm{~min}$ and rinsed three times by agitation with MilliQ ${ }^{\circledR}$ water for $15 \mathrm{~min}$. The seedling roots and shoots were then oven-dried at $105^{\circ} \mathrm{C}$ for $24 \mathrm{~h}$ and $0.5 \mathrm{~g}$ material was digested using $10 \mathrm{ml}$ of $\mathrm{HNO}_{3}$ in a microwave oven (CEM, MARS Xpress) according to the USEPA 3052 method (USEPA, 1995). After mineralization, the plant extracts were filtered $(0.2 \mu \mathrm{m}$ PTFE), diluted and analyzed. Total content of $\mathrm{Ce}$ and Ti was determined by an ICPOES (Varian Inc., Vista MPX). The accuracy of the analytical procedure adopted for ICP-OES analysis was checked by running standard solutions every 20 samples. Yttrium was used as the internal standard.

\section{TEM Observations and X-ray Microanalysis}

The morphology of NPs was assessed by direct observation of suspension of $n \mathrm{CeO}_{2}$ or $n \mathrm{TiO}_{2}$ NPs under the TEM. Drops of suspensions (prepared as described above) were placed on carbon-formvar coated nickel grids, dried at room temperature and observed under a Philips CM 10 (FEI, Eindhoven, The Netherlands) TEM, operating at $80 \mathrm{kV}$.

For microscopic analyses in planta, tissues from seedlings treated with $n \mathrm{CO}_{2}$ or $n \mathrm{TiO}_{2}$ at 1000 and $2000 \mathrm{mg} \mathrm{l}^{-1}$ were sampled as in the root elongation experiment were sampled. Roots and shoots were excised, cut into small portions $(2 \mathrm{~mm} \times 3 \mathrm{~mm})$ and fixed for $2 \mathrm{~h}$ at $4^{\circ} \mathrm{C}$ in $0.1 \%$ (w/vol) buffered sodium phosphate and $3 \%(\mathrm{w} / \mathrm{v})$ glutaraldehyde at $\mathrm{pH}$ 7.2. They were then post-fixed with $1 \%$ osmium tetroxide $(\mathrm{w} / \mathrm{v})$ in the same buffer for $2 \mathrm{~h}$, dehydrated in an ethanol series, and embedded in Epon/Araldite epoxy resin (Electron Microscopy Sciences, Fort Washington, PA, USA). For conventional TEM observations, serial ultrathin sections from embedded leaf tissues were cut with a diamond knife, mounted on uncoated 200 mesh copper grids (Electron Microscopy Sciences, Fort Washington, PA, USA), stained in uranyl acetate and lead citrate, and then observed under TEM as reported above.

For X-ray microanalysis, unstained ultrathin sections were placed on formvar/carbon-coated 200 mesh nickel grids and dried at room temperature. The nature of NPs observed in plant tissues was determined by a TEM (PHILIPS CM 12, FEI, Eindhoven, The Netherlands) equipped with an EDSX-ray microanalysis system (EDAX, AMETEK, Mahwah NJ, USA, software EDAX Genesis). The images were recorded by 
a Megaview G2 CCD Camera (Olympus; software iTEM FEI, Analysis Image Processing).

\section{Data Analysis}

One-way analysis of variance (ANOVA) was conducted to test differences in the plants' behavior. Tukey's Multiple Comparison test at $0.05 p$ level were used to compare means. Statistical analyses were performed using the SPSS program (SPSS Inc., Chicago, IL, USA, ver. 17). Principal Coordinate Analysis (PCoA) was computed based on the binary genetic distance option in GenAlEx v. 6.501 software (Peakall and Smouse, 2012). Graphics were produced using CoPlot (CoHort ver. 6.204, Monterey, CA, USA).

\section{RESULTS}

\section{Nanoparticles Characterization}

The specific surface values obtained by BET measurements were $46.1 \mathrm{~m}^{2} \mathrm{~g}^{-1}$ for $n \mathrm{CeO}_{2}$ and $61.6 \mathrm{~m}^{2} \mathrm{~g}^{-1}$ for $n \mathrm{TiO}_{2}$. The $\mathrm{Z}$-average sizes of the $n \mathrm{CeO}_{2}$ and $n \mathrm{TiO}_{2}$ suspended in deionized water were $174 \pm 1.2 \mathrm{~nm}$ and $925 \pm 105 \mathrm{~nm}$, respectively, these values result remarkable higher respect the declared producer dimensions. The zeta potentials were $0.027 \pm 0.064 \mathrm{mV}$ for $n \mathrm{CeO}_{2}$ and $19.9 \pm 0.55 \mathrm{mV} n \mathrm{TiO}_{2}$. These parameter values put in evidence their instability, in fact for both NP types are included in the range of the NP instability $(-30 \mathrm{mV} \div+30 \mathrm{mV})$ and justify the differences between the declared dimension and the measured ones. The PDI of $n \mathrm{CeO}_{2}$ and $n \mathrm{TiO}_{2}$ were $0.339 \pm 0.011$ and $0.841 \pm 0.173$, respectively. These values indicate a narrow dimensional distribution of $n \mathrm{CeO}_{2}$ respect to $n \mathrm{TiO}_{2}$.

\section{Caryopses Germination and Root Elongation}

Effects of $n \mathrm{CeO}_{2}$ and $n \mathrm{TiO}_{2}$ on caryopses germination and root growth are shown in Table 1. Since there was not a statistically significant effect of concentrations for $n \mathrm{CeO}_{2}$ and $n \mathrm{TiO}_{2}$, our results demonstrate that, even at the highest level of concentration, caryopses germination is not affected by $n \mathrm{CeO}_{2}$ or $n \mathrm{TiO}_{2}$ (Table 1). At the end of our experiment the barley seedlings had reached coleoptile emergence. At this stage typically has between six and seven seminal roots (Knipfer and Fricke, 2011). In our experiment the number of seminal roots was not affected by $n \mathrm{CeO}_{2}$ and $n \mathrm{TiO}_{2}$ (Table 1). On the contrary, in both cases the development of root tissues was influenced in a similar manner by the treatments. In fact, there was a significant effect of both $n \mathrm{CeO}_{2}(p<0.05)$ and $n \mathrm{TiO}_{2}(p<0.05)$ on the average length of the seminal roots. Post hoc comparison tests indicated that root elongation in seedlings treated with $500 \mathrm{mg}$ $1^{-1} n \mathrm{CeO}_{2}$ and $n \mathrm{TiO}_{2}$ was significantly lower than controls (24.5 and $-14.8 \%$, respectively). At higher $n \mathrm{CeO}_{2}$ and $n \mathrm{TiO}_{2}$ concentrations we would have expected to see a further reduction in the development of seminal roots. However, this did not occur since the average length of seminal roots was similar to controls (Table 1).

\section{Cerium and Titanium in Plant Tissues}

Although without visible symptoms of phytotoxicity, the concentration of total $\mathrm{Ce}$ and $\mathrm{Ti}$ in the tissues of barley seedlings showed (i) a dose-response and (ii) a different magnitude of accumulation between $\mathrm{Ce}$ and Ti. Table 2 shows the concentration of $\mathrm{Ce}$ and $\mathrm{Ti}$ in the fractions of barley seedlings. As expected $\mathrm{Ce}$ and $\mathrm{Ti}$ accumulated much more within root tissues than in the shoot $(p<0.05)$. Ce concentration in the roots increased significantly $(p<0.05)$ as the concentration of $n \mathrm{CeO}_{2}$ in the growth medium increased (Table 2). A statistically significant effect of treatments in Ce accumulation in the shoots $(p<0.001)$ was verified. Mean comparisons showed differences among the treatments. Ce concentration in shoots did not significantly differ between the 500 and $1000 \mathrm{mg} \mathrm{l}^{-1}$ Ce treatment (38.3 and $98.1 \mathrm{mg} \mathrm{Ce}$ $\mathrm{kg}^{-1} \mathrm{DW}$, respectively), whereas at $2000 \mathrm{mg} n \mathrm{CeO}_{2} \mathrm{~L}^{-1}$ a Ce concentration of $622 \mathrm{mg} \mathrm{Ce} \mathrm{kg}^{-1} \mathrm{DW}$ was observed in the shoots, which is significantly different from other values (Table 2).

Titanium concentrations in barley roots and shoots were onetwo orders of magnitude lower compared to Ce. However, also in this case a statistically significant dose dependent increase was also observed. With the lowest $n \mathrm{TiO}_{2}$ treatment $(500 \mathrm{mg}$ $\left.1^{-1}\right) \mathrm{Ti}$ concentration in roots was negligible and no $\mathrm{Ti}$ was detected in shoots (Table 2). At the intermediate $n \mathrm{TiO}_{2}$ treatment $\left(1000 \mathrm{mg} \mathrm{l}^{-1}\right)$ the root tissues had $37.2 \mathrm{mg} \mathrm{Ti} \mathrm{kg}^{-1} \mathrm{DW}$ which is significantly lower $(p=0.0001)$ than $413 \mathrm{mg} \mathrm{Ti} \mathrm{kg}^{-1} \mathrm{DW}$ found at highest $n \mathrm{TiO}_{2}$ treatment (Table 2). Finally, we verified that also $\mathrm{Ti}$ concentration in the shoots also responded positively to the treatments $(p<0.001)$. The mean Ti concentration detected in barley shoots were $7.83 \mathrm{mg} \mathrm{kg}^{-1} \mathrm{DW}$ and $26.2 \mathrm{mg} \mathrm{kg}^{-1} \mathrm{DW}$ for 1000 and $2000 \mathrm{mg} \mathrm{nTiO}_{2} \mathrm{l}^{-1}$, respectively (Table 2).

TABLE 1 | Germination percentage of seeds, number of seminal roots and root length in barley seedlings treated with $0,500,100$, and $2000 \mathrm{mg} \mathrm{I}^{-1}$ of $n \mathrm{CeO}_{2}$ and $n \mathrm{TiO}_{2}$.

\begin{tabular}{|c|c|c|c|c|c|c|}
\hline \multirow[t]{2}{*}{ Treatment } & \multicolumn{3}{|c|}{$n \mathrm{CeO}_{2}$} & \multicolumn{3}{|c|}{$n \mathrm{TiO}_{2}$} \\
\hline & Germination (\%) & Seminal roots $(n)$ & Root length (mm) & Germination (\%) & Seminal roots $(n)$ & Root length (mm) \\
\hline $500 \mathrm{mg} \mathrm{I}^{-1}$ & $83 \pm 2.03 a$ & $5.5 \pm 0.22 a$ & $39.8 \pm 2.24 b$ & $87 \pm 1.76 \mathrm{a}$ & $6.1 \pm 0.27 a$ & $45.4 \pm 2.85 b$ \\
\hline $1000 \mathrm{mg} \mathrm{l}^{-1}$ & $80 \pm 2.08 \mathrm{a}$ & $5.2 \pm 0.26 a$ & $45.8 \pm 17.8 \mathrm{ab}$ & $85 \pm 1.45 \mathrm{a}$ & $6.5 \pm 0.22 \mathrm{a}$ & $53.9 \pm 3.13 \mathrm{a}$ \\
\hline $2000 \mathrm{mg} \mathrm{I}^{-1}$ & $79 \pm 1.86 \mathrm{a}$ & $4.9 \pm 0.25 a$ & $43.8 \pm 1.72 \mathrm{ab}$ & $87 \pm 1.76 \mathrm{a}$ & $6.4 \pm 0.13 a$ & $58.5 \pm 2.97 \mathrm{a}$ \\
\hline
\end{tabular}

Values are mean $\pm S E(n=3)$. Different letters indicate statistical difference between treatments at Tuckey's test $(p<0.05)$. 
TABLE 2 | Concentration of total $\mathrm{Ce}$ and $\mathrm{Ti}$ in roots and shoots of barley seedlings treated with $0,500,100$, and $2000 \mathrm{mg} \mathrm{I}^{-1}$ of $n \mathrm{CeO} 2$ and $n \mathrm{TiO}_{2}$.

\begin{tabular}{|c|c|c|c|c|}
\hline Treatment & Ce roots $\left(\mathrm{mg} \mathrm{kg}^{-1} \mathrm{DW}\right)$ & Ce coleoptile (mg kg-1 DW) & Ti roots $\left(\mathrm{mg} \mathrm{kg}^{-1} \mathrm{DW}\right)$ & Ti coleoptile $\left(\mathrm{mg} \mathrm{kg}^{-1} \mathrm{DW}\right)$ \\
\hline Ctrl & $<$ d.l. & $<$ d.l. & $<$ d.l. & $<$ d.l. \\
\hline $500 \mathrm{mg} \mathrm{I}^{-1}$ & $579 \pm 168 b$ & $38.3 \pm 5.77 b$ & $<$ d.l. & $<$ d.l. \\
\hline $2000 \mathrm{mg} \mathrm{l}^{-1}$ & $20,714 \pm 5722 \mathrm{a}$ & $622 \pm 95.1 \mathrm{a}$ & $412 \pm 127 \mathrm{a}$ & $26.2 \pm 8.71 \mathrm{a}$ \\
\hline
\end{tabular}

Values are mean $\pm S E(n=3)$. Different letters indicate statistical difference between treatments at Tuckey's test $(p<0.05)$.

\section{Ce and Ti Nano-aggregates in Plant Tissues}

The morphology of $n \mathrm{CeO}_{2}$ and $n \mathrm{TiO}_{2}$ NPs is visible in Figures $\mathbf{1 A}, \mathbf{B}$, respectively. Transmission electron microscopy analysis demonstrated that $\mathrm{CeO}_{2}$ particles exhibited an approximate equi-axes shape with sharp edges (Figure 1A), while particle sharp edges are less evident in $\mathrm{TiO}_{2}$. To assess the possible uptake of $n \mathrm{CeO}_{2}$ or $n \mathrm{TiO}_{2}$ from the culture medium to the root tissues and the translocation to the different parts of the plantlets, we performed ultrastructural analyses on roots and shoot tissues. Several clusters of NPs were found in cortical parenchymal tissues of roots, both in the case of $n \mathrm{CeO}_{2}$ (Figure 2A) and $n \mathrm{TiO}_{2}$ treatment, at all concentrations. Clusters were also observed in the xylem, even if in to lesser extent (Figure 2B). EDS-X ray microanalysis allowed the identification of the clusters as aggregates of $\mathrm{Ce}$ and Ti nanoparticles.

No NPs were detected in the shoots of $n \mathrm{CeO}_{2}$ or $n \mathrm{TiO}_{2}$ treated plantlets. The ultrastructure of all observed tissues appeared preserved. No necrosis or damage to membranes, nor cell modifications were detected. In general, the cell compartments were not significantly affected by treatments, except for the nuclei of parenchymal cells of root and shoot of seedlings treated with $n \mathrm{CeO}_{2}$ (1000 and $2000 \mathrm{mg} \mathrm{l}^{-1}$ ), which showed compact chromatin (Figures 3A-D).

\section{ATP and ROS}

The evaluation of ATP concentration aimed to evidence the energetic status in different fractions of barley seedlings exposed to $n \mathrm{CeO}_{2}$ and $n \mathrm{TiO}_{2}$. The different concentrations of $n \mathrm{CeO}_{2}$ induced a statistically significant effect (Figure 4), with a trend of values peaking at 500 and $1000 \mathrm{mg} \mathrm{l}^{-1}$, in root and lowering at $2000 \mathrm{mg} \mathrm{l}^{-1}$ in shoot samples. The highest $n \mathrm{CeO}_{2}(2000 \mathrm{mg}$ $\mathrm{l}^{-1}$ ) reached a low concentration of ATP in roots, statistically comparable to control samples. On the contrary, $n \mathrm{TiO}_{2}$ induce no significant changes of ATP concentration, since different $n \mathrm{TiO}_{2}$ doses were similar to the controls in both roots and shoots (Figure 4).

The measurement of ROS was performed as marker for oxidative stress. Similarly to ATP content, $n \mathrm{CeO}_{2}$ were able to induce an increase of a ROS formation at all the concentrations assayed (Figure 5), in comparison with the control, although no statistically significant differences were observed. Also for this parameter, a trend with a peak at $500 \mathrm{mg} \mathrm{l}^{-1}$ was present in both roots and shoots. In the case of $n \mathrm{TiO}_{2}$ (Figure 5), the treatments did not show any difference, if compared with the control in roots, whereas a decrease of ROS level was observed at the higher dose $\left(2000 \mathrm{mg} \mathrm{l}^{-1}\right)$ in shoots.

\section{Mitotic Index and RAPDs}

The mitotic index was significantly reduced by $n \mathrm{CeO}_{2} 2000 \mathrm{mg}$ $1^{-1}$ (from $4 \pm 1.2 \%$ in the control to $2.4 \pm 1.2 \%$ ). Instead, the $n \mathrm{CeO}_{2} 500$ and $1000 \mathrm{mg} \mathrm{l}^{-1}$ treatments with mean values of $4 \pm 1.3 \%$ were very similar to the control (Figure $6 \mathrm{~A}$ ). The treatments with $n \mathrm{TiO}_{2}$ with values of $6.2 \pm 3.2 \%, 4.6 \pm 3.2 \%$, $4.9 \pm 2.5 \%$ for the concentration at 500,1000 , and $2000 \mathrm{mg}$ $1^{-1}$, respectively, were not significantly different from the control $(4.9 \pm 2.8 \%$; Figure 6A).

The six primers used for the RAPD analysis amplified for a total of 40 representative bands in controls with a variable number of 3 to $9(9,5,6,3,9,8$, bands, respectively, for OPA04, OPB01, OPA10, OPB20, OPB12, and OPB03). Amplification was highly reproducible since the same RAPD profile was observed within control replicates. A concentration effect was observed for the $n \mathrm{CeO}_{2}$ treatments on the RAPD profiles. The same banding pattern as controls was obtained for the $n \mathrm{CeO}_{2} 500 \mathrm{mg} \mathrm{l}^{-1}$ treatment, whereas new profiles at $1000 \mathrm{mg} \mathrm{l}^{-1}$ were observed and three additional bands appeared and eight disappeared. Even greater variability was observed at $n \mathrm{CeO}_{2} 2000 \mathrm{mg} \mathrm{l}^{-1}$ with a total of 20 differences (appearing and disappearing bands) in treated plants (Figures 6B,C). The results were summarized by Principal Coordinates Analysis (PCoA), with almost $94 \%$ of the total variability explained by the two axes (Figure 6D). The overlap of the control and $500 \mathrm{mg} \mathrm{l}^{-1}$ treatments is notable, while the treatments at 1000 and $2000 \mathrm{mg} \mathrm{l}^{-1}$ are well separated in different quadrants. The band polymorphism in the different replicates at the higher concentration $\left(2000 \mathrm{mg} \mathrm{l}^{-1}\right)$ can be noticed by the point cloud (Figure 6D). In a similar way to what was observed fro the mitotic index, the $n \mathrm{TiO}_{2}$ treatments at each concentration have no effect on the RAPD profiles (Figure 6D).

\section{DISCUSSION}

Since plant nanotoxicology is a new field of investigation, specific ecotoxicological methods for the estimation of toxicity of ENPs have not yet been developed (Jośko and Oleszczuk, 2014). According to OECD guidelines, the acute effects of MeNPs on plant physiology are currently investigated by adapting the methods already used for traditional contaminants (Kühnel and Nickel, 2014). Evidence of MeNPs plant uptake and toxicity are still scarce and contradictory (Etheridge et al., 2013). This is likely because, compared to their bulk counterparts, MeNPs show particular properties, which are subjected to transformations (e.g., redox reactions, aggregation or agglomeration, and dissolution) according to different environmental factors. These 


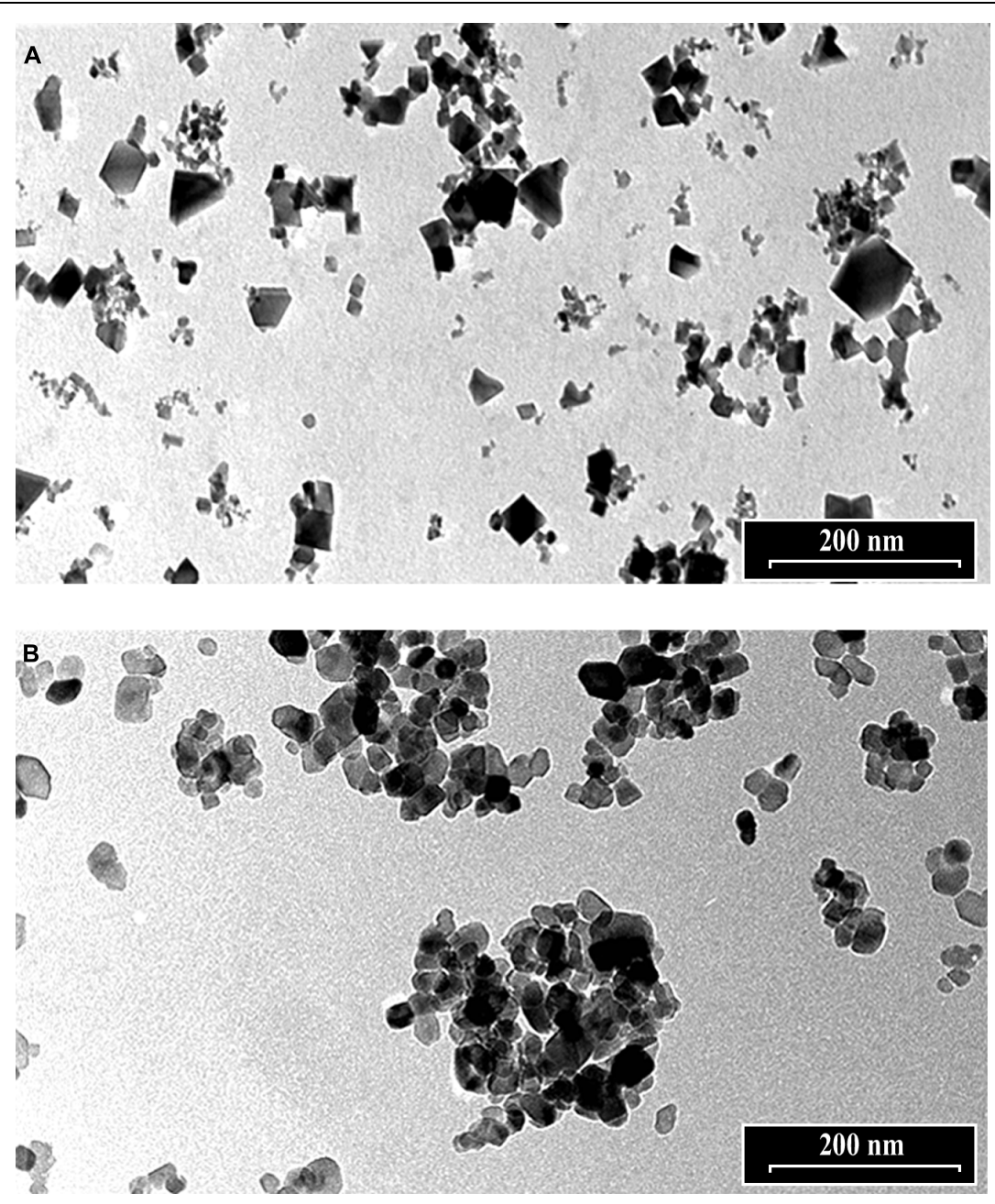

FIGURE 1 | Transmission electron microscope images of $1000 \mathrm{mg} \mathrm{l}^{-1}$ suspensions of $(\mathrm{A}) n \mathrm{CeO}_{2}$ and $(\mathrm{B}) n \mathrm{TiO}_{2}$.

changes might modify the ecotoxicological properties of MeNPs and thus, their interactions with the biota (Nowack et al., 2012; Maurer-Jones et al., 2013). However, despite these limitations, the experimental results obtained so far offer early indications on MeNPs phytotoxicity (Li et al., 2015; Rico et al., 2015a). Our data suggests that also in very simple experimental conditions, $n \mathrm{TiO}_{2}$, as expected taking into account their intrinsic properties, forms bigger agglomerates with a wider dimensional distribution than $n \mathrm{CeO}_{2}$.

\section{$n \mathrm{CeO}_{2}$ and $n \mathrm{TiO}_{2}$ Affects Seed Germination and Seedling Development}

Previous studies carried out in controlled conditions reported that the toxicity of MeNPs in the early stages of plant growth is likely due to the following factors: (i) chemical and physical properties which influence the release of ions or the aggregation of particles in more stable forms and (ii) the size and shape of the particles, which determine the specific surface area of MeNPs (Yang and Watts, 2005; Lin and Xing, 2007).
In agreement with Rico et al. (2015b), we found that germination of barley was unaffected by $500-2000 \mathrm{mg} \mathrm{l}^{-1}$ $n \mathrm{CeO}_{2}$. This is in contrast with the results provided by López-Moreno et al. (2010a) who reported that suspensions of $2000 \mathrm{mg} \mathrm{l}^{-1} n \mathrm{CeO}_{2}$ significantly reduced seed germination in maize, cucumber, tomato, and soybean. Possible explanations could be the greater Ce tolerance of barley to the treatment if compared to other species and/or to the very small size of Ce NPs they used $(7 \mathrm{~nm})$. Another explanation could be related to the chemical and physical properties of $n \mathrm{CeO}_{2}$, in particular his zeta potential value. This parameter is the cause of the agglomeration behavior of the $n \mathrm{CeO}_{2}$ that brings to a low bioavailability and the absence of phytotoxic effects on the treated seeds regards the germination percentage.

Another important issue that plays a role on seed/NP interaction, is the methodology adopted for seed treatment. In fact, following Lin and Xing (2007), we prepared the barley seeds for germination trials by soaking them in distilled water before starting treatments, whereas López-Moreno et al. (2010a) 


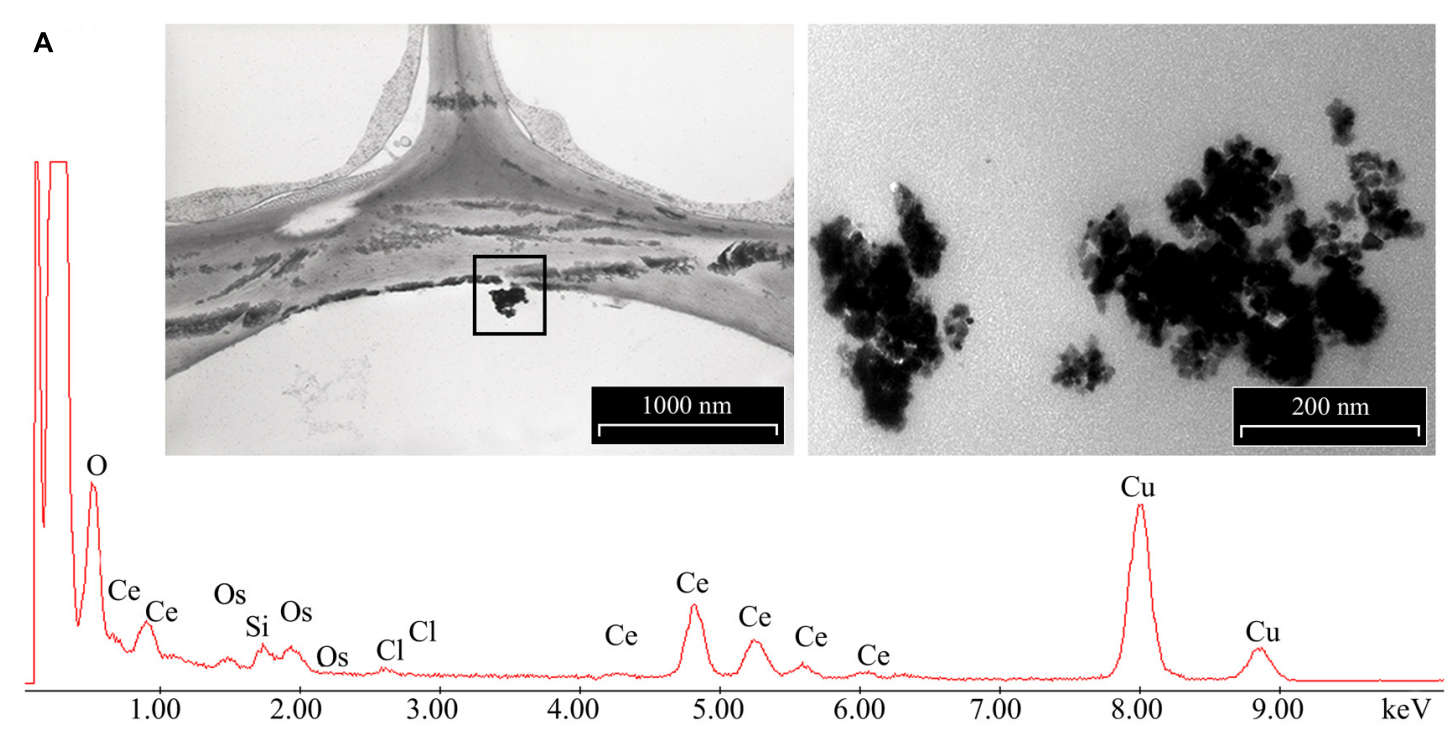

B

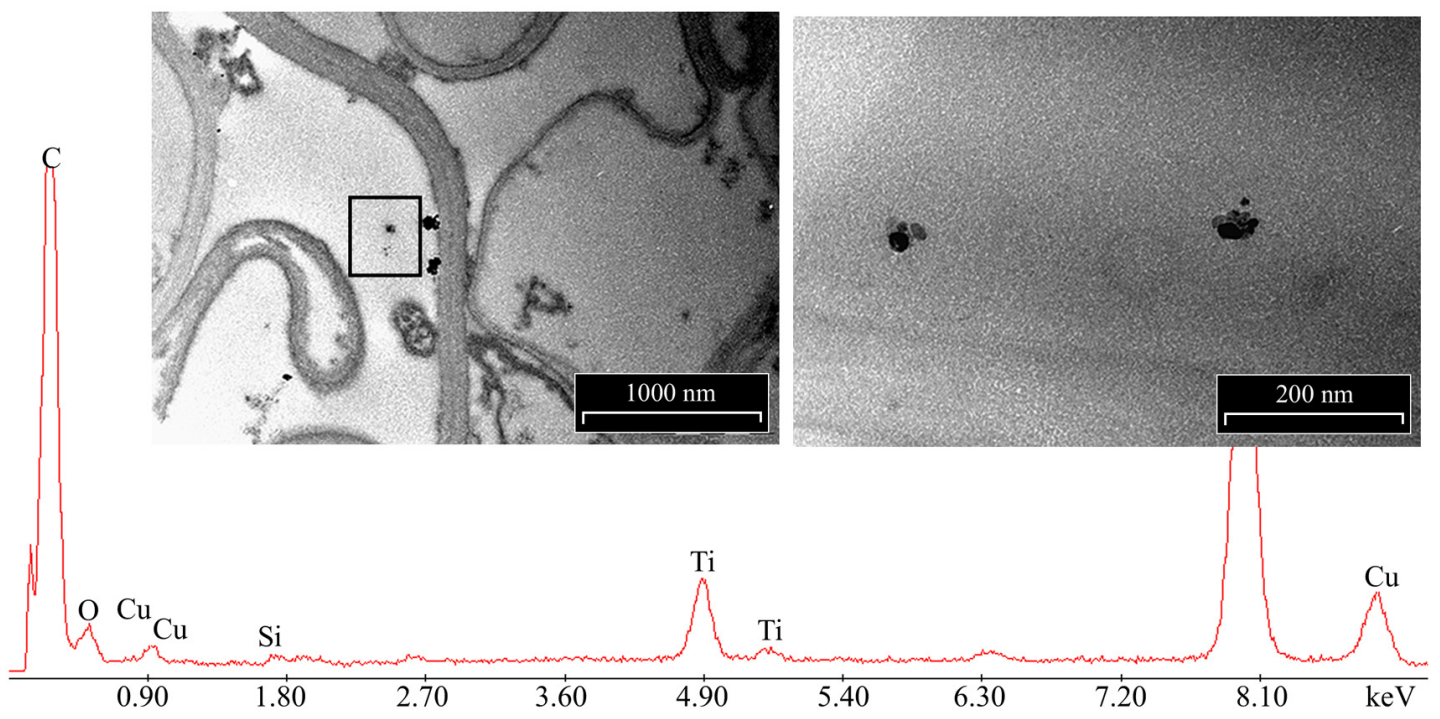

FIGURE 2 | Representative images of electron dense precipitates recovered in root tissues of Hordeum vulgare exposed to $1000 \mathrm{mg} \mathrm{I}^{-1} \mathrm{of}_{(\mathrm{A})} n \mathrm{CeO}_{2}$ and $(\mathrm{B}) n \mathrm{TiO}_{2}$ and $\mathrm{X}$-ray spectra of elements recovered in. Insets represent enlarged regions where X-ray microanalyses have been performed. Presence of $\mathrm{C}$, Os were due to sample preparation, Cu to the grids used as section support.

soaked the seeds directly in the $n \mathrm{CeO}_{2}$ suspensions. This different experimental approach could result in a different exposure of germinating seeds to $n \mathrm{CeO}_{2}$.

As regards $\mathrm{Ti}$, there is a substantial agreement in literature on the fact that suspensions of $n \mathrm{TiO}_{2}$ do not affect seed germination, with few exceptions, as reported by Zheng et al. (2005) and Feizi et al. (2012). Our results are in accordance with those reported by other authors on rice, lettuce, radish, cucumber, tomato, and pea (Boonyanitipong et al., 2011; Wu et al., 2012; Song et al., 2013a; Fan et al., 2014).

Besides the germination percentage, we observed a negative influence of the treatments with $n \mathrm{CeO}_{2}$ and $n \mathrm{TiO}_{2}$ on root elongation in barley seedlings. However, this did not occur in seedlings treated with $n \mathrm{CeO}_{2}$ at the highest concentration, in which the root length was very similar to controls. In addition, in this case the literature reports contradictory evidence. LópezMoreno et al. (2010a) reported that the root growth in maize and cucumber seedlings was significantly promoted by $n \mathrm{CeO}_{2}$ (up to $4000 \mathrm{mg} \mathrm{l}^{-1}$ ) whereas the same treatments resulted in a negative effect on root development in alfalfa and tomato. An inhibitory effect of $n \mathrm{TiO}_{2}$ on root elongation in cucumber was reported by Mushtaq (2011). A decrease in the number of secondary lateral roots in pea seedlings was verified by Fan et al. (2014), whereas Boonyanitipong et al. (2011) did not record any effect on root length in rice seedlings exposed to $n \mathrm{TiO}_{2}$. In our case, the different effect of the $n \mathrm{CeO}_{2}$ and $n \mathrm{TiO}_{2}$ on the root 


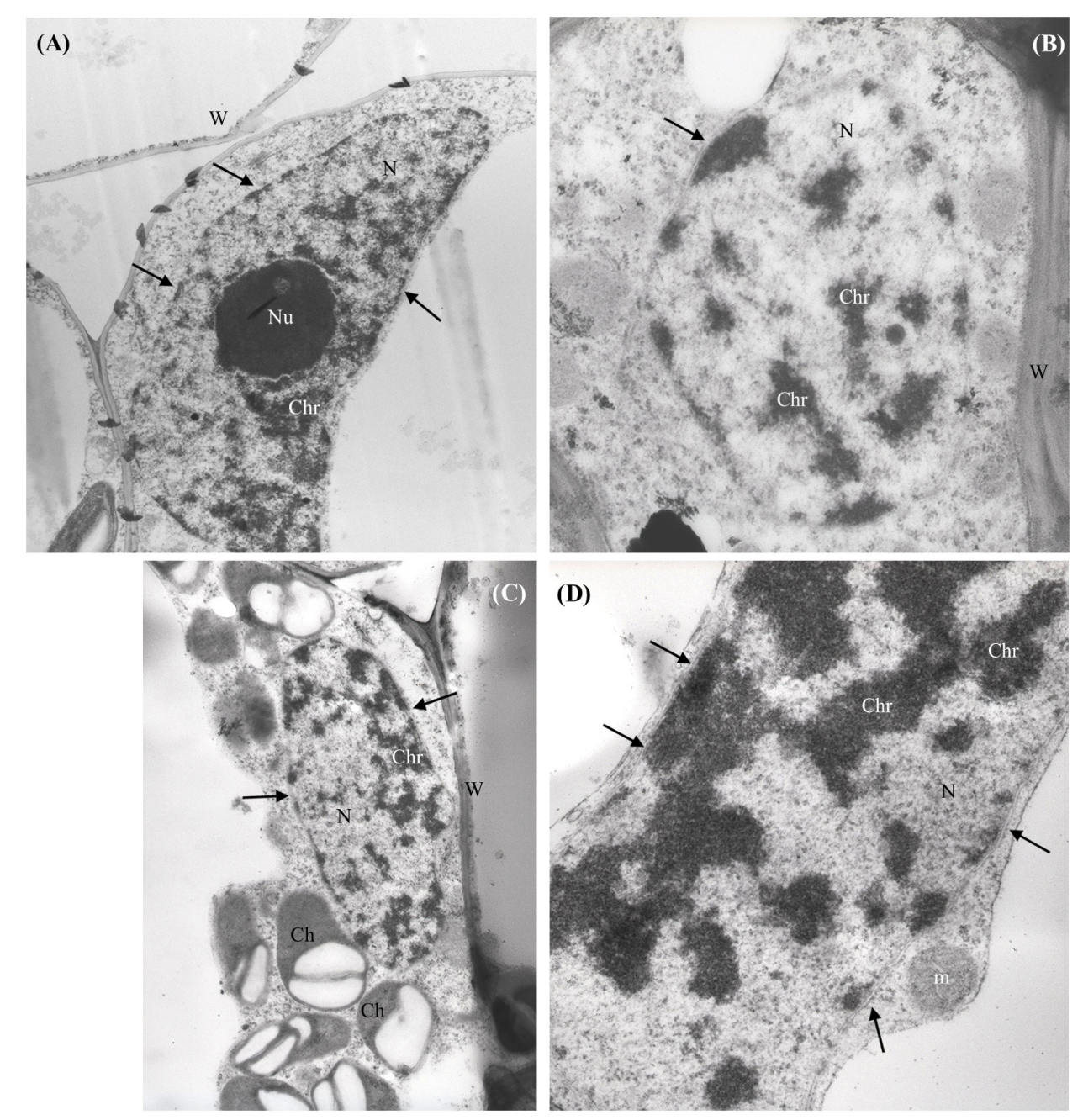

FIGURE 3 | Representative micrographs of nuclei (N) from shoot (A-C) and root (D) parenchymal cells of Hordeum vulgare. (A) Control untreated shoot: nucleus presents regular shape, nuclear membranes are intact (arrows), nucleolus (Nu) and chromatin (Chr) appear normally dispersed. (B,C) 1000 mg $n$ CeO $2 I^{-1}$ treated shoot and (D), $1000 \mathrm{mg} n \mathrm{CeO}_{2} \mathrm{I}^{-1}$ - treated root: nuclei still present normal shape and apparently undamaged membranes, while chromatin shows condensation. Ch, chloroplasts; $\mathrm{m}$, mitochondrion.

elongation is likely due to their different grade of agglomeration demonstrated by the $\mathrm{z}$-average size and PDI values of $n \mathrm{TiO}_{2}$ that results significantly higher than $n \mathrm{CeO}_{2}$.

It might happen that the quantification analysis of trace metals in plant roots is disturbed by external contamination. In this case, the concentration of the element in the plant tissues could be significantly overestimated due to a fraction of metal, which is not taken up but simply adsorbed onto the external root surface. In our experiment, a concentration of $\mathrm{Ce}$ about 60 times greater than $\mathrm{Ti}$, was found in barley root tissues. This substantial difference indicates that the procedures for preparation of the samples were conducted properly; otherwise, we would also have very high concentrations also for $\mathrm{Ti}$.

Our results showed that the exposure of $H$. vulgare to $n \mathrm{CeO}_{2}$, which are smaller and less aggregated than $n \mathrm{TiO}_{2}$, resulted in a greater total Ce concentration in roots compared to $\mathrm{Ti}$. In can therefore be assumed that, for some still unknown reasons, the model of root uptake of the two elements could differ, depending in part on the intrinsic properties of solubility and agglomeration properties of $n \mathrm{CeO}_{2}$ and $n \mathrm{TiO}_{2}$. On the other hand, this is in agreement with the findings by Zhang et al. (2011), who verified that cucumber roots absorbed higher amounts of $7 \mathrm{~nm}$ $n \mathrm{CeO}_{2}$ than $25 \mathrm{~nm}$ ones. On the other, some studies pointed out the possibility of interactions between the root metabolism and MeNPs. Lin and Xing (2007) demonstrated that root exudates such as proteins, phenolic acids, and aminoacids have a role in the adsorption of $\mathrm{ZnO}$ NPs to the root surface of perennial ryegrass. More recently, Schwabe et al. (2015) observed that root uptake of dissolved $\mathrm{Ce}^{(\mathrm{III})}$ was promoted by the dissolution of $n \mathrm{CeO}_{2}$ at the medium-root interface in hydroponically growth sunflower and maize. A further confirmation about the role of root exudates on the adsorption of MeNPs was provided by LV et al. (2015) and $\mathrm{Ma}$ et al. (2015), respectively, for $n \mathrm{CeO}_{2}$ and $n \mathrm{ZnO}$, respectively. However, $\mathrm{Lv}$ et al. (2015) reported that a 

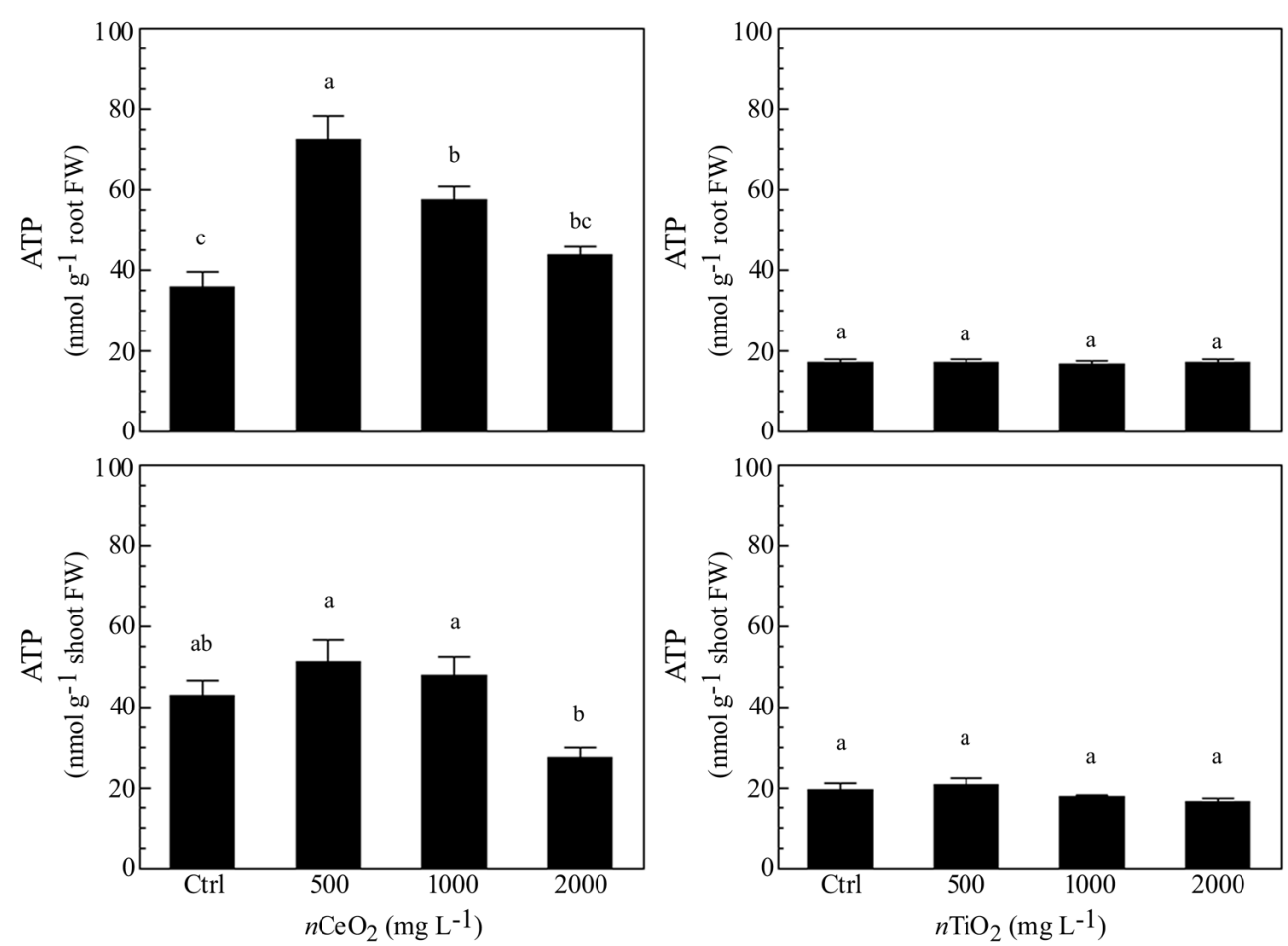

FIGURE 4 | Determination of ATP concentration in extracts obtained from plantlets of barley roots and shoots, grown on wet paper filters, in the presence of different concentrations of $n \mathrm{CeO}_{2}$ and $n \mathrm{TiO}_{2}$.
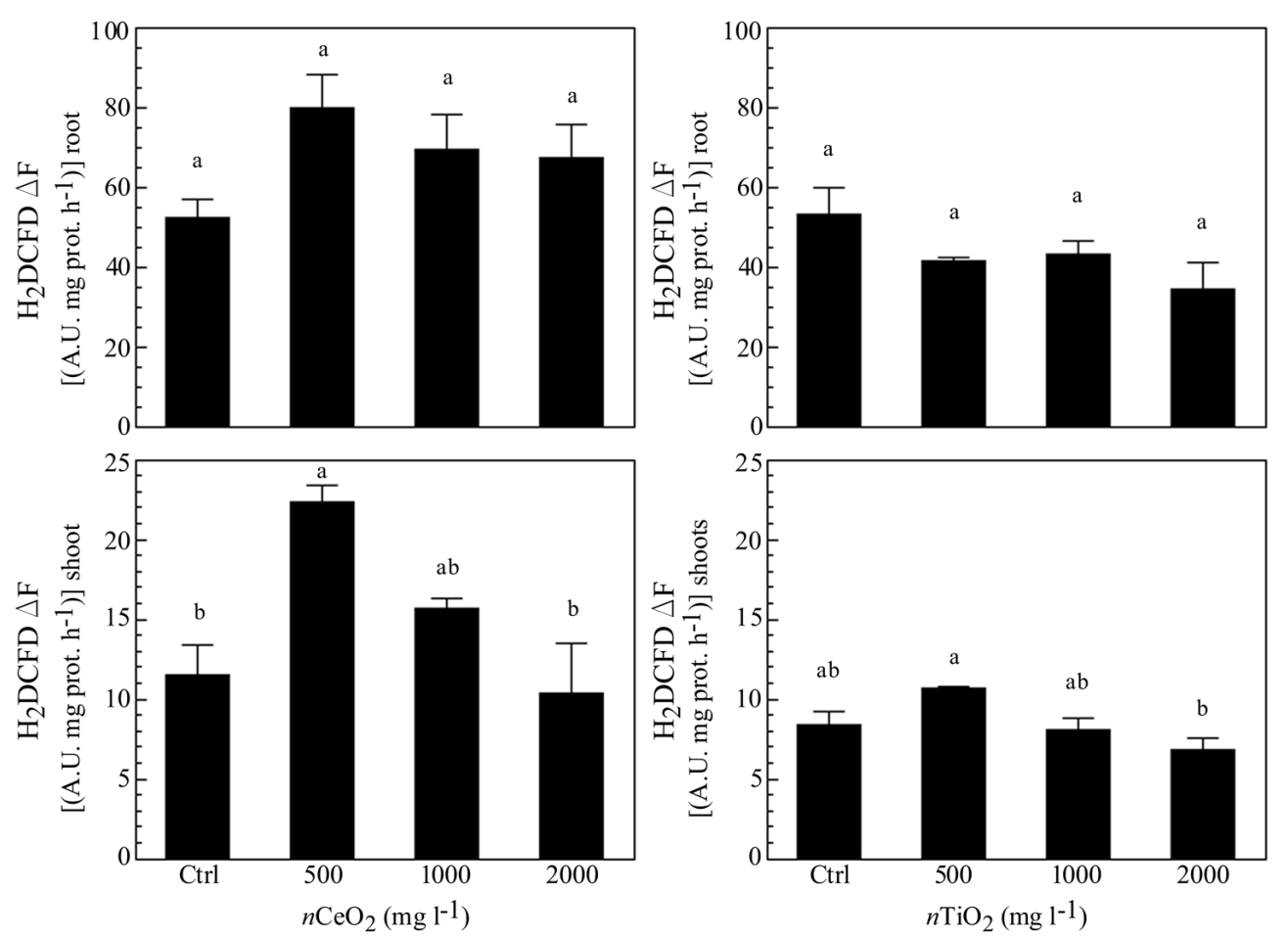

FIGURE 5 | Evaluation of reactive oxygen species (ROS) evolution in extracts obtained from plantlets of barley roots and shoots, grown on wet paper filters, in the presence of different concentrations of $\boldsymbol{n} \mathbf{C e O}_{2}$ and $\boldsymbol{n} \mathrm{TiO}_{2}$. The analysis was performed by means of a fluorimetric probe. 

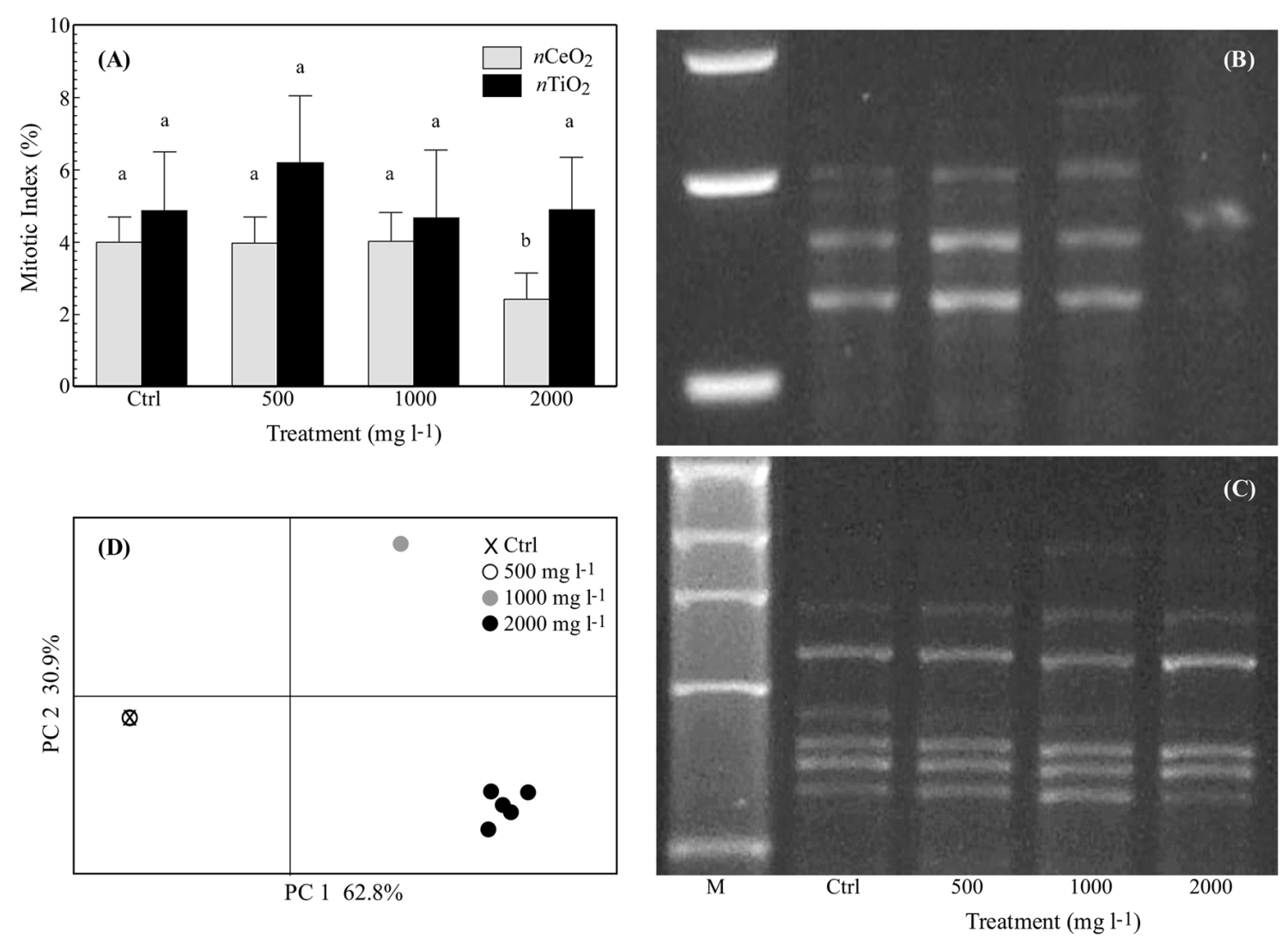

FIGURE 6 | (A) Mitotic index (\%; mean \pm SE) observed in root tips of seedlings of barley treated with 0-2000 $\mathrm{mg} \mathrm{I}^{-1}$ of $n \mathrm{CeO}_{2}$ and $n \mathrm{TiO} \mathrm{O}_{2}$. Different letters indicate statistical difference between treatments at Tuckey's test $(p<0.05)$. (B,C) Representative RAPD profiles from the roots of barley seedlings treated with $n C e \mathrm{O}_{2}$ (B) or $n \mathrm{TiO}_{2}$ (C) at control, 500-2000 mg I-1. The shown RAPD profiles were generated using primer $\mathrm{OPAO}^{-1}$ for $n \mathrm{CeO}_{2}$ (it is shown an enlargement around polymorphic zone) and OPB12 for $n \mathrm{TiO}_{2}$. The first line is a $1 \mathrm{~kb}$ DNA marker (M). (D) Principal coordinate analysis (PCoA) based on RAPD profiles from the barley roots with $n \mathrm{CeO}_{2}$. Values on axes indicate the variance explained.

possible access of $n \mathrm{ZnO}$ to the root tissues could be through the root apex or the meristematic zone to the lateral root system where the Casparian strip is not yet developed.

Root-to-shoot translocation of $n \mathrm{CeO}_{2}$ has been previously described in soybean (Priester et al., 2012), tomato (Wang et al., 2012), cucumber (Zhao et al., 2013), and cotton (Van Nhan et al., 2015) after treatments with $n \mathrm{CeO}_{2}$ suspensions. Different observations have been made on $n \mathrm{CeO}_{2}$ root-toshoot translocation in graminaceous crops. Schwabe et al. (2013) reported that wheat does not translocate $n \mathrm{CeO}_{2}$ into the aerial tissues, whereas Rico et al. $(2013,2015 \mathrm{a})$ reported the translocation of $n \mathrm{CeO}_{2}$ from roots to rice grains and maize kernels, respectively. According to Rico et al. (2015b), we report evidence of Ce translocation from roots to the aerial part of barley. As regards Ti uptake and translocation, fewer data are available in the literature compared. However, our data are consistent with the findings reported by Song et al. (2013b) on tomato seedlings exposed to $\mathrm{Ti}$ at concentrations ranging from 50 to $5000 \mathrm{mg} \mathrm{l}^{-1}$.

Finally, we reported that root length in barley seedlings treated with $500 \mathrm{mg} n \mathrm{CeO}_{2} \mathrm{l}^{-1}$ was significantly shorter than controls. This apparent dose-effect was not confirmed at higher $n \mathrm{CeO}_{2}$ concentrations, since the root length was similar to that of controls. Similar evidence was reported by López-Moreno et al. (2010a). According to Nascarella and Calabrese (2012) and Bell et al. (2014), such unexpected results might be interpreted as a hormetic effect of $n \mathrm{CeO}_{2}$ on root elongation in barley seedlings.

\section{Plant Stress Induced by Nanoparticle Treatments}

Within the plants, NPs may interact with the host cells, causing different effects, ranging from cell death (if the host is sensitive) to not relevant cell modifications (in the case of host tolerance), depending on their type, shape, and concentration (Rico et al., 2011; Gardea-Torresdey et al., 2014). The microscopic observations on barley seedlings indicated that both $n \mathrm{CeO}_{2}$ and $n \mathrm{TiO}_{2}$, at the used concentrations used, were able to enter the root tissues, being detected in the parenchymal cells and xylem vessels. Even though we did not observe $\mathrm{Ce}$ and $\mathrm{Ti}$ crystalline aggregates in the shoots, ICP analyses suggested a root-to-shoot mobilization of $\mathrm{Ce}$ and $\mathrm{Ti}$ ions. At histological level the accumulation of such elements induced limited injuries. On the contrary, important differences in the effects of treatments were obtained at nuclear level, where 
only the $n \mathrm{CeO}_{2}$ treatments induced visible modifications in the chromatin aggregation in the nuclei of root and shoot parenchymal cells.

Condensed chromatin and fragmented nuclei are described as part of the programmed cell death (PCD), occurring in response to different environmental stimuli and stresses, induced by pathogens (Lam et al., 2001) and by diverse abiotic factors (White, 1996; Kratsch and Wise, 2000) including the exposition to nanomaterials (Shen et al., 2010). PCD plays an important role in mediating plant adaptation to the environment. In cells that undergo programmed death, chromatin condenses into masses with sharp margins, and DNA is hydrolyzed into a series of fragments (Gladish et al., 2006). Dynamic compaction of chromatin is an important step in the DNA-damage response, because it activates DNAdamage-repair signaling (Burgess et al., 2014) in response to injuries.

The hypothesis of Ce-induced DNA damage in treated seedlings finds further support in the results obtained with the RAPD test. RAPD can potentially detect a broad range of DNA damage and mutations, so it is suitable for studying MeNPs genotoxicity (Atienzar and Jha, 2006). The RAPD modified patterns at high concentrations of $n \mathrm{CeO}_{2}(1000-$ $2000 \mathrm{mg} \mathrm{l}^{-1}$ ) indicated a genotoxic effect, which could directly influence the cell cycle. This is further confirmed by the reduced mitotic index recorded in the samples treated with $n \mathrm{CeO}_{2} 2000 \mathrm{mg} \mathrm{l}^{-1}$, which clearly demonstrated the negative effect of high $n \mathrm{CeO}_{2}$ concentrations on the cell cycle. Our results are in agreement with López-Moreno et al. (2010b), who demonstrated $n \mathrm{CeO}_{2}$ genotoxicity on soybean plants subjected to treatments similar to those reported in our work.

It is still far too early to conclude if the observed effects were direct or indirect consequences of the treatments, since $n \mathrm{CeO}_{2}$ were not found in the nucleus. As it is known that increasing oxidative stress leads to DNA damage, the higher presence of ROS in treated samples could cause modification in RAPD patterns. However, as our analysis on ROS indicated a peak at $500 \mathrm{mg}$ $n \mathrm{CeO}_{2} \mathrm{l}^{-1}$, it can be rationalized that lower concentrations triggered an initial oxidative signal, while only higher $n \mathrm{CeO}_{2}$ doses were able to induce damage at nuclear level. The oxidative stress peak at $500 \mathrm{mg} \mathrm{l}^{-1}$ dose and could be rationalized by the well-known SOD mimetic activity attributable to $n \mathrm{CeO}_{2}$, which could cause a dismutation of superoxide anions into $\mathrm{H}_{2} \mathrm{O}_{2}$. Since a similar pattern is also found for ATP measured in $n \mathrm{CeO}_{2}$ treated tissues, it is suggested that the oxidative burst induced by the more effective dose of $n \mathrm{CeO}_{2}$ could be associated to a stimulation of cellular respiration and a consequent increase in ATP production. This could be due to a defense response signal or an increased requirement for energy (Vranová et al., 2002).

On the contrary, the $n \mathrm{TiO}_{2}$ treatments did not influence either the mitotic index or RAPD pattern. This is in contrast to Moreno-Olivas et al. (2014) who observed $n \mathrm{TiO}_{2}$-induced genotoxicity in hydroponically cultivated zucchini. As the size of $n \mathrm{TiO}_{2}$ they reported is comparable to that used in our work, the different results obtained can be explained by (i) the different cultivation systems (Petri dishes vs. full nutrient solution in hydroponics) and (ii) the $n \mathrm{TiO}_{2}$ concentration used by Moreno-Olivas et al. (2014; 10-fold smaller). The latter potentially prevents the formation of big NP agglomerates, making them more bioavailable.

\section{CONCLUSION}

Although investigations into the effects of NPs in plants continue to increase, there are still many unresolved issues and challenges, in particular at the biota-nanomaterial interface (Nowack et al., 2015). In this multidisciplinary work, we studied the phytotoxic and genotoxic impact of $n \mathrm{CeO}_{2}$ and $n \mathrm{TiO}_{2}$ cerium and titanium oxide NP suspensions on the early growth of barley. Seed germination was not affected by the $n \mathrm{CeO}_{2}$ and $n \mathrm{TiO}_{2}$ suspensions, indicating that $n \mathrm{CeO}_{2}$ and $n \mathrm{TiO}_{2}$ are not allowed to enter the seed coatings. However, we verified that the concentration of $\mathrm{Ce}$ and $\mathrm{Ti}$ in the seedling fractions, as well as the root-toshoot translocation, were dose-dependent. Then, we found signals of genotoxicity (RAPD banding patterns and mitotic index) and phytotoxicity in root cells (oxidative stress and chromatin modifications) resulting in a shortage of root elongation.

The different magnitude of bioaccumulation of $\mathrm{Ce}$ and Ti suggests a different uptake mechanism, likely due to the different behavior of $n \mathrm{CeO}_{2}$ and $n \mathrm{TiO}_{2}$. Recent studies have shown that plant toxic effects of nanomaterials are not merely due to the particle size and concentration of a suspension. Phytotoxicity of metal oxide NPs is related both to the direct adsorption of particles onto the root structures and to the aptitude of the metal ion to dissolve, possibly mediated by binding molecules produced by plants in the medium-root interface.

Our study had not the objective to investigate the details of the mechanisms by which the NPs entering within the roots. However, we verified the presence of both $n \mathrm{CeO}_{2}$ and $n \mathrm{TiO}_{2}$ into the root cells where an increase in oxidative stress occurred. More research needs to be conducted to verify whether germination can be affected by smaller $n \mathrm{CeO}_{2}$ and $n \mathrm{TiO}_{2}$. In addition, we need to understand if modification of the physical-chemical properties of NPs at the root interface can foster the plant uptake of Ce and $\mathrm{Ti}$ forms.

\section{AUTHOR CONTRIBUTIONS}

$\mathrm{AM}$ conducted the experiments. $\mathrm{AF}$ and $\mathrm{AB}$ provided the biochemical parameters. FP performed out the ICP and RAPD analysis. RM made TEM observation and observed MeNPs distribution in planta. CG and MS carried out TEM-EDAX observations. MV contributed to the mitotic index. LM designed, coordinated the study, performed statistical analysis, and prepared the figures. All authors were involved in manuscript writing. All authors contributed to the revision of the manuscript. 


\section{ACKNOWLEDGMENTS}

This work was in part supported by a project funded by DISA - Department of Agriculture and Environmental Sciences, University of Udine, through Grant n.64 dd. 08-09.2014 (RANDOLPH - Relazioni tra nanoparticelle metalliche e piante

\section{REFERENCES}

Atha, D. H., Wang, H., Petersen, E. J., Cleveland, D., Holbrook, D., Jaruga, P., et al. (2012). Copper oxide nanoparticle mediated DNA damage in terrestrial plant models. Environ. Sci. Technol. 46, 1819-1827. doi: 10.1021/es202660k

Atienzar, F. A., and Jha, A. N. (2006). The random amplified polymorphic DNA (RAPD) assay and related techniques applied to genotoxicity and carcinogenesis studies: a critical review. Mutat. Res. 613, 76-102. doi: 10.1016/j.mrrev.2006.06.001

Bell, I. R., Ives, J. A., and Jonas, W. B. (2014). Nonlinear effects of nanoparticles: biological Variability from Hormetic Doses, small particle sizes, and dynamic adaptive interactions. Dose Response 12, 202-232. doi: 10.2203/dose-response.13-025.Bell

Boonyanitipong, B., Kositsup, B., Kumar, P., Baruah, S., and Dutta, J. (2011). Toxicity of $\mathrm{ZnO}$ and $\mathrm{TiO}_{2}$ nanoparticles on germinating rice seed Oryza sativa L. Int. J. Biosci. Biochem. Bioinform. 1, 282-285. doi: 10.7763/IJBBB.2011.V1.53

Bradford, M. (1976). A rapid and sensitive method for the quantitation of microgram quantities of protein utilizing the principle of protein-dye binding. Anal. Biochem. 72, 248-254. doi: 10.1016/0003-2697(76)90527-90523

Burgess, R. C., Burman, B., Kruhlak, M. J., and Misteli, T. (2014). Activation of DNA damage response signaling by condensed chromatin. Cell Rep. 9, 1703-1717. doi: 10.1016/j.celrep.2014.10.060

Clément, L., Hurel, C., and Marmier, N. (2013). Toxicity of $\mathrm{TiO}_{2}$ nanoparticles to cladocerans, algae, rotifers and plants - Effects of size and crystalline structure. Chemosphere 90, 1083-1090. doi: 10.1016/j.chemosphere.2012.09.013

Colman, B. P., Arnaout, C. L., Anciaux, S., Gunsch, G. K., Hochella, M. F. Jr., Kim, B., et al. (2013). Low concentrations of silver nanoparticles in biosolids cause adverse ecosystem responses under realistic field scenario. PLoS ONE 8:e57189. doi: 10.1371/journal.pone.0057189

Etheridge, M. L., Campbell, S. A., Erdman, A. G., Haynes, C. L., Wolf, S. M., and McCullough, J. (2013). The big picture on nanomedicine: the state of investigational and approved nanomedicine products. Nanomed. Nanotechnol. Biol. Med. 9, 1-14. doi: 10.1016/j.nano.2012.05.013

Fan, R., Huang, Y. C., Grusak, M. A., Huang, C. P., and Sherrier, D. J. (2014). Effects of nano-TiO(2) on the agronomically-relevant Rhizobium-legume symbiosis. Sci. Total Environ. 466-467, 503-512. doi: 10.1016/j.scitotenv.2013.07.032

FAOSTAT (2014). Food and Agricultural Commodities Production: Commodities by Regions. Available at: http://faostat3.fao.org/faostat-gateway/ go/to/browse/ranking/commodities_by_regions/E [accessed Sept 4, 2015]

Feizi, H., Moghaddam, P. R., Shahtahmassebi, N., and Fotovat, A. (2012). Impact of bulk and nanosized titanium dioxide $\left(\mathrm{TiO}_{2}\right)$ on wheat seed germination and seedling growth. Biol. Trace Elem. Res. 146, 101-106. doi: 10.1007/s12011-0119222-7

Gardea-Torresdey, J. L., Rico, C. M., and White, J. C. (2014). Trophic transfer, transformation and impact of engineered nanomaterials in terrestrial environments. Environ. Sci. Technol. 48, 2526-2540. doi: 10.1021/es40 50665

Gladish, D. K., Xu, J., and Niki, T. (2006). Apoptosis-like programmed cell death occurs in procambium and ground meristem of Pea (Pisum sativum) root tips exposed to sudden flooding. Ann. Bot. 97, 895-902. doi: 10.1093/aob/m cl040

Gogos, A., Knauer, K., and Bucheli, T. D. (2012). Nanomaterials in plant protection and fertilization: current state, foreseen applications, and research priorities. J. Agric. Food Chem. 60, 9781-9792. doi: 10.1021/jf302154y

Hong, J., Peralta-Videa, J. R., and Gardea-Torresdey, J. L. (2013). "Nanomaterials in agricultural production: benefits and possible threats?" in Sustainable Nanotechnology and the Environment: Advances and Achievements, eds $\mathrm{N}$. Shamim and V. K. Sharma, ACS Symposium Series (Washington, DC: American Chemical Society). superiori). The authors acknowledge technical assistance in the use of BET by Anastasios Papadiamantis and access to the lab facilities of the Environmental Nanoscience research group at Birmingham University (UK). The authors also thank Francesco Bertolini and Nicola Zorzin for their relevant contribution to the work.

Jośko, I., and Oleszczuk, P. (2014). Phytotoxicity of nanoparticles-problems with bioassay choosing and sample preparation. Environ. Sci. Pollut. Res. 21, 10215-10224. doi: 10.1007/s11356-014-2865-0

Keller, A., McFerran, S., Lazareva, A., and Suh, S. (2013). Global life cycle releases of engineered nanomaterials. J. Nanopart. Res. 15, 1692. doi: 10.1007/s11051013-1692-4

Knipfer, T., and Fricke, W. (2011). Water uptake by seminal and adventitious roots in relation to whole-plant water flow in barley (Hordeum vulgare L.). J. Exp. Bot. 62, 717-733. doi: 10.1093/jxb/erq312

Kratsch, H. A., and Wise, R. R. (2000). The ultrastructure of chilling stress. Plant Cell Environ. 23, 337-350. doi: 10.1046/j.1365-3040.2000.00560.x

Kühnel, D., and Nickel, C. (2014). The OECD expert meeting on ecotoxicology and environmental fate - Towards the development of improved OECD guidelines for the testing of nanomaterials. Sci. Tot. Environ. 472, 347-353. doi: 10.1016/j.scitotenv.2013.11.055

Lam, E., Kato, N., and Lawton, M. (2001). Programmed cell death, mitochondria and the plant hypersensitive response. Nature 411, 848-853. doi: $10.1038 / 35081184$

Li, K.-E., Chang, Z.-Y., Shen, C.-X., and Yao, N. (2015). “Toxicity of nanomaterials to plants," in Nanotechnology and Plant Sciences, eds M. H. Siddiqui, M. H. Al-Whaibi, and F. Mohammad (Cham: Springer International Publishing), $101-124$.

Lin, D., and Xing, B. (2007). Phytotoxicity of nanoparticles: inhibition of seed germination and root growth. Environ. Pollut. 150, 243-250. doi: 10.1016/j.envpol.2007.01.016

Liu, H. H., and Cohen, Y. (2014). Multimedia environmental distribution of engineered nanomaterials. Environ. Sci. Technol. 48, 3281-3292. doi: $10.1021 / \mathrm{es} 405132 \mathrm{z}$

López-Moreno, M. L., de La Rosa, G., Hernández-Viezcas, J. A., Peralta-Videa, J. R., and Gardea-Torresdey, J. L. (2010a). X-ray Absorption Spectroscopy (XAS) corroboration of the uptake and storage of $\mathrm{CeO}_{2}$ nanoparticles and assessment of their differential toxicity in four edible plant species. J. Agric. Food Chem. 58, 3689-3693. doi: 10.1021/jf904472e

López-Moreno, M. L., de la Rosa, G., Hernandez-Viezcas, J. A., Castillo-Michel, H., Botez, C. E., Peralta-Videa, J. R., et al. (2010b). Evidence of the differential biotransformation and genotoxicity of $\mathrm{ZnO}$ and $\mathrm{CeO}_{2}$ nanoparticles on soybean (Glycine max) plants. Environ. Sci. Technol. 44, 7315-7320. doi: $10.1021 /$ es903891g

Lundin, A. (1984). Extraction and Automatic Luminometric Assay of ATP, ADP and $A M P$. New York: Academic Press.

Lv, J., Zhang, S., Luo, L., Zhang, J., Yang, K., and Christie, P. (2015). Accumulation, speciation and uptake pathway of $\mathrm{ZnO}$ nanoparticles in maize. Environ. Sci. Nano 2, 68-77. doi: 10.1039/c4en00064a

Ma, Y., Zhang, P., Zhang, Z., He, X., Zhang, J., Ding, Y., et al. (2015). Where does the transformation of precipitated ceria nanoparticles in hydroponic plants take place? Environ. Sci. Technol. 49, 10667-10674. doi: 10.1021/acs.est.5b02761

Maurer-Jones, M. A., Gunsolus, I. L., Murphy, C. J., and Haynes, C. L. (2013). Toxicity of engineered nanoparticles in the environment. Anal. Chem. 85, 3036-3049. doi: 10.1021/ac303636s

Miralles, P., Church, T. L., and Harris, A. T. (2012). Toxicity, Uptake, and Translocation of engineered nanomaterials in vascular plants. Environ. Sci. Technol. 46, 9224-9239. doi: 10.1021/es202995d

Moreno-Olivas, F., Gant, V. U. Jr., Johnson, K. L., Peralta-Videa, J. R., and GardeaTorresdey, J. L. (2014). Random amplified polymorphic DNA reveals that TiO2 nanoparticles are genotoxic to Cucurbita pepo. J. Zhejiang Univ. Sci. A 15, 618-623. doi: 10.1631/jzus.A1400159

Mushtaq, Y. K. (2011). Effect of nanoscale $\mathrm{Fe}_{3} \mathrm{O}_{4}, \mathrm{TiO}_{2}$ and carbon particles on cucumber seed germination. J. Environ. Sci. Health A 46, 1732-1735. doi: 10.1080/10934529.2011.633403 
Nascarella, M. A., and Calabrese, E. J. (2012). A method to evaluate hormesis in nanoparticle dose-response. Dose Response 10, 344-354. doi: 10.2203/doseresponse.10-025

Navarro, E., Baun, A., Behra, R., Hartmann, N. B., Filser, J., Miao, A.-J., et al. (2008). Environmental behavior and ecotoxicity of engineered nanoparticles to algae, plants, and fungi. Ecotoxicology 17, 372-386. doi: 10.1007/s10646-008-0214-0

Nowack, B., Baalousha, M., Bornhöft, N., Chaudhry, O., Cornelis, G., Cotterill, J., et al. (2015). Progress towards the validation of modelled environmental concentrations of engineered nanomaterials by analytical measurements. Environ. Sci. Nano 2, 421-428. doi: 10.1039/c5en00100e

Nowack, B., Ranville, J. F., Diamond, S., Gallego-Urea, J. A., Metcalfe, C., Rose, J., et al. (2012). Potential scenarios for nanomaterial release and subsequent alternation in the environment. Environ. Toxicol. Chem. 31, 50-59. doi: 10.1002 /etc. 726

OECD (2010). List of Manufactured Nanomaterials and List of Endpoints for Phase One of the Sponsorship Programme for the Testing of Manufactured Nanomaterials: Revision. Paris: OECD Environment, Health and Safety Publications Series on the Safety of Manufactured Nanomaterials.

Parisi, C., Vigani, M., and Rodríguez-Cerezo, E. (2015). Agricultural nanotechnologies: what are the current possibilities? Nano Today 10, 124-127. doi: 10.1016/j.nantod.2014.09.009

Peakall, R., and Smouse, P. E. (2012). GenAlEx 6.5: genetic analysis in Excel. Population genetic software for teaching and research - an update. Bioinformatics 28, 2537-2539. doi: 10.1093/bioinformatics/bts460

Piccinno, F., Gottschalk, F., Seeger, S., and Nowack, B. (2012). Industrial production quantities and uses of ten engineered nanomaterials in Europe and the world. J. Nanopart. Res. 14, 1109. doi: 10.1007/s11051-012-1109-9

Priester, J. H., Ge, Y., Mielke, R. E., Horst, A. M., Moritz, S. C., Espinosa, K., et al. (2012). Soybean susceptibility to manufactured nanomaterials with evidence for food quality and soil fertility interruption. Proc. Natl. Acad. Sci. U.S.A. 109, E2451. doi: 10.1073/pnas.1205431109

Rico, C., Morales, M., Barrios, A., McCreary, R., Hong, J., Lee, W., et al. (2013). Effect of cerium oxide nanoparticles on the quality of rice (Oryza sativa L.) grains. J. Agric. Food Chem. 61, 11278-11285. doi: 10.1021/jf404046v

Rico, C. M., Majumdar, S., Duarte-Gardea, M., Peralta-Videa, J. R., and GardeaTorresdey, J. L. (2011). Interaction of nanoparticles with edible plants and their possible implications in the food chain. J. Agric. Food Chem. 59, 3485-3498. doi: $10.1021 /$ jf104517j

Rico, C. M., Peralta-Videa, J. R., and Gardea-Torresdey, J. L. (2015a). “Chemistry, biochemistry of nanoparticles, and their role in antioxidant defense system in plants," in Nanotechnology and Plant Sciences, eds M. H. Siddiqui, M. H. Al-Whaibi, and F. Mohammad (Cham: Springer International Publishing), $1-18$.

Rico, C. M., Peralta-Videa, J. R., and Gardea-Torresdey, J. L. (2015b). Differential effects of cerium oxide nanoparticles on rice, wheat, and barley roots: a Fourier Transform Infrared (FT-IR) microspectroscopy study. Appl. Spectrosc. 69, 287295. doi: 10.1366/14-07495

Roco, M. M. (2011). The long view of nanotechnology development: the National Nanotechnology Initiative at 10 years. J. Nanopart. Res. 13, 427-445. doi: 10.1007/s11051-010-0192-Z

Schneider, C. A., Rasband, W. S., and Eliceiri, K. W. (2012). NIH Image to ImageJ: 25 years of image analysis. Nat. Methods 9, 671-675. doi: 10.1038/nmeth.2089

Schwabe, F., Schulin, R., Limbach, L. K., Stark, W., and Burge, D. (2013). Influence of two types of organic matter on interaction of $\mathrm{CeO}_{2}$ nanoparticles with plants in hydroponic culture. Chemosphere 91, 512-520. doi: 10.1016/j.chemosphere.2012.12.025

Schwabe, F., Tanner, S., Schulin, R., Rotzetter, A. C., Stark, W. J., Von Quadt, A., et al. (2015). Dissolved cerium contributes to uptake of Ce in presence of differently sized $\mathrm{CeO}_{2}$-nanoparticles by three crop plants. Metallomics 7, 466477. doi: 10.1039/c4mt00343h
Shen, C. S., Zhang, Q.-F., Li, J., Bi, F.-C., and Yan, N. (2010). Induction of programmed celle death in Arabidopsis and rice by single-wall carbon nanotubes. Am. J. Bot. 97, 1602-1609. doi: 10.3732/ajb.1000073

Song, U., Jun, H., Waldman, B., Roh, J., Kim, Y., Yi, J., et al. (2013a). Functional analysis of nanoparticle toxicity: a comparative study of the effects of $\mathrm{TiO}_{2}$ and Ag on tomatoes (Lycopersicon esculentum). Ecotoxicol. Environ. Safe. 93, 60-67. doi: 10.1016/j.ecoenv.2013.03.033

Song, U., Shin, M., Lee, G., Roh, J., Kim, Y., and Lee, E. J. (2013b). Functional Analysis of TiO2 Nanoparticle toxicity in three plant species. Biol. Trace Elem. Res. 155, 93-103. doi: 10.1007/s12011-013-9765-x

USEPA (1995). EPA Method 3052: Microwave Assisted Acid Digestion of Siliceous and Organically Based Matrices, 3rd Edn. Washington, DC: Test Methods for Evaluating Solid Waste.

Van Hoecke, K., Quik, J. T., Mankiewicz-Boczek, J., De Schamphelaere, K. A., Elsaesser, A., Van der Meeren, P., et al. (2009). Fate and effects of $\mathrm{CeO}_{2}$ nanoparticles in aquatic ecotoxicity tests. Environ. Sci. Technol. 15, 4537-4546. doi: 10.1021/es9002444

Van Nhan, L., Ma, C., Rui, Y., Liu, S., Li, X., Xing, B., et al. (2015). Phytotoxic mechanism of nanoparticles: destruction of chloroplasts and vascular bundles and alteration of nutrient absorption. Sci. Rep. 5, 11618. doi: 10.1038/srep 11618

Vranová, E., Inzé, D., and Van Breusegem, F. (2002). Signal transduction during oxidative stress. J. Exp. Bot. 53, 1227-1236. doi: 10.1093/jexbot/53.372.1227

Wang, H., and Joseph, J. A. (1999). Quantifying cellular oxidative stress by dichlorofluorescein assay using microplate reader. Free Radic. Biol. Med. 27, 612-616. doi: 10.1016/S0891-5849(99)00107-0

Wang, Q., Ma, X., Zhang, W., Pei, H., and Chen, Y. (2012). The impact of cerium oxide nanoparticles on tomato (Solanum lycopersicum L.) and its implications for food safety. Metallomics 4, 1105-1112. doi: 10.1039/C2MT20149F

White, E. (1996). Life, death, and the pursuit of apoptosis. Genes Dev. 10, 1-15. doi: 10.1101/gad.10.1.1

Wu, S. G., Huang, L., Head, J., Chen, D. R., Kong, I. C., and Tang, Y. J. (2012). Phytotoxicity of metal oxide nanoparticles is related to both dissolved metals ions and adsorption of particles on seed surfaces. J. Pet. Environ. Biotechnol. 3, 126. doi: 10.4172/2157-7463.1000126

Yang, L., and Watts, D. J. (2005). Particle surface characteristics may play an important role in phytotoxicity of alumina nanoparticles. Toxicol. Lett. 158, 122-132. doi: 10.1016/j.toxlet.2005.03.003

Zhang, Z., He, X., Zhang, H., Ma, Y., Zhang, P., Ding, Y., et al. (2011). Uptake and distribution of ceria nanoparticles in cucumber plants. Metallomics 3, 816-822. doi: $10.1039 / \mathrm{clmt} 00049 \mathrm{~g}$

Zhao, L., Youping, S., Hernandez-Viezcas, J. A., Servin, A., Hong, J., Genhua, N., et al. (2013). Influence of $\mathrm{CeO} 2$ and $\mathrm{ZnO}$ nanoparticles on cucumber physiological markers and bioaccumulation of $\mathrm{Ce}$ and $\mathrm{Zn}$ : a life cycle study. J. Agric. Food Chem. 61, 11945-11951. doi: 10.1021/jf404328e

Zheng, L. F., Lu, S., and Liu, C. (2005). Effect of nano- $\mathrm{TiO}_{2}$ on strength of naturally aged seeds and growth of spinach. Biol. Trace Elem. Res. 104, 83-91. doi: 10.1385/BTER:104:1:083

Conflict of Interest Statement: The authors declare that the research was conducted in the absence of any commercial or financial relationships that could be construed as a potential conflict of interest.

Copyright (c) 2015 Mattiello, Filippi, Pošćić, Musetti, Salvatici, Giordano, Vischi, Bertolini and Marchiol. This is an open-access article distributed under the terms of the Creative Commons Attribution License (CC BY). The use, distribution or reproduction in other forums is permitted, provided the original author(s) or licensor are credited and that the original publication in this journal is cited, in accordance with accepted academic practice. No use, distribution or reproduction is permitted which does not comply with these terms. 